\title{
Assessment of Land Use and Land Cover Changes in Panchrakhi Village, Hugli District, West Bengal, India
}

\author{
Dipanwita De ${ }^{1}$, Sayani Banerjee ${ }^{2}$, Sumana Ghosh ${ }^{3}$ \\ Department of Geography, Swami Niswambalananda Girls' College, Bhadrakali, Hugli, 712232, West Bengal, \\ India \\ ${ }^{2}$ Department of Geography Majdia Rail Bazar High School, Majdia, Nadia, India \\ ${ }^{3}$ Department of Geography, Swami Niswambalananda Girls' College, Bhadrakali, Hugli, 712232, West Bengal, \\ India
}

\begin{abstract}
The term land use may be defined as the putting up parcel of land for any purposes. Presence of human being on earth and his use of land had profound effect on the natural environment and vice versa; which results into an observable change in the land use and land cover over time. The study of land use is an urgent for resource planning, cultural advancement as well as overall development of a nation. The present study attempts to identify the spatio- temporal changes of land use land cover in Panchrakhi village of district Hugli, over the time span of 40 years. The study reveals that the orchard farming is an important land use pattern of this area but very recently it is decreasing at a slow pace. Vegetation cover of this region is almost wiped out and built up land is extending quite usually with growing population pressure.
\end{abstract}

Key Words: cultural advancement, land cover, land use, resource planning, spatio-temporal change.

\section{Introduction}

The anthropogenic activities changed the natural landscape significantly with the passage of time. A change in land use land cover is being increasingly recognized as critical factors influencing the global change (Sharma et al 2008). However, we must keep in mind that though the term land use and land cover are often casually assumed as identical to each other but there is basic differences between these two. Land use is the functional dimensions of land for different human purposes and economic activities and is often shaped by human, socio-economic and political influences (Sharma et al 2008) while land cover may be defined as the biophysical coverage of the earth surface. Study of land use land cover change provides better understanding of previous practices, current land use pattern and also the future planning over land. In modern era, adequate information is needed to make rational decision about better administration, business, and establishment of institutions or industries, planning natural resource management, environmental protection and so on Economic and cultural advancement can better be carried out only through the systematic and balanced utilization of land. Consequently, the knowledge about land use and land cover has become gaining importance day by day.

\section{Literature Review}

The study of land use dates back to as early as eighteenth century and most of them are based on rural agro resources. Adam Smith (1776), Alfred Marshall (1890) were some of the pioneers of the early land use studies. Their works are still serving as foundation of the most of the present day theories. Here we must mention that L.D. Stamp was one of the greatest workers in land use studies. His valuable work has provided primary guidelines to the geographers and planners to carry out research work on land use in different parts of the world In United States land survey was carried out to record the use of selected land unit as well as to assess the degree of limitations to land use. A comprehensive hand book of land use was published 1961 (Klingebiel and Montgomery, 1961). Hudson (1971), Young (1976), Olson (1974) of US department of Agriculture have contributed a lot in this regard. In 1963 the Canadian land inventory unit did the land capability assessment in Canada to provide basis for resource and land use planning. Gradually the countries like Britain, USA, Canada, France, Poland, Italy, etc. are concentrating on land use studies. Inspired by the classical work of Stamp the Indian Geographers initiated land use studies in different parts of the country. Chatterjee (1941) pointed out the agency of land use study in India. According to him different types of land use land cover reflect an intricate pattern which needs geographical investigation in respect to their physical environment. He carried out land use land cover survey on Howrah district and 24 Parganas of West Bengal (Chatterjee 1945, 1952). The study reveals poor drainage condition of the district although with large rivers and also discussed the impact of soil and climate on land utilization, population pressure on land, trade and transport, nature of land utilization and agricultural implements. Mukherjee (1967) observed the changing land use pattern in Howrah district and suggested planning strategies for agricultural land use. Roy (1972) emphasised on the relationship between land 
use and agricultural characteristics of Damodar-Saraswati Doab area. Chatterjee and Jana (1975) studied the pattern of land utilization in an around Tarakeswar town of Hooghly district. Chattopadhyay (1980) tried to correlate hydrology and land use in the littoral tract of West Bengal. Change detection is the process of identifying differences in the state of an object or phenomenon by observing it at different points in time (Singh 1989). Roy and Giriraj (2008) have also done a meaningful study over land use and land cover analysis in Indian context. Prakasam (2010) studied the land use and land cover change in Kodaikanal region of Western Ghats in Tamilnadu State of India to observe changes during a span of 40 years from 1969 to 2008. The present study conducted and assessment on land use land cover change of Panchrakhi village of Polba-Dadpur block of Hugli district with an aim identifying changes due to human activities and impact on the land resource. In the present study we have studied the general spatial pattern of land use land cover and made an up to date land use land cover study in Panchrakhi village. The study has also summarized past 40 years change of land use land cover and searched the cause behind it.

\section{Materials and Methods}

We have identified the spatial and temporal Land use land cover changes of past 40 years from Survey of India topographical map (Map No.79 B/5), Cadastral map of Panchrakhi village .To explore the reality and present land use and land cover of the study area, we have carried out plot to plot land use survey of the concerned area. The land use land cover categories include agricultural land, natural vegetation, built-up, surface water bodies, fallows etc. This classification is performed based on the standard classification scheme.

\section{Study Area}

The Panchrakhi village is under Polba-Dadpur block of Hugli district under Burdwan Sub division of the state West Bengal. Geographical location of this village is between $23^{\circ} 54^{\prime} 35^{\prime \prime}$ to $23^{\circ} 55^{\prime} 10^{\prime \prime}$ North latitude and $88^{\circ} 20^{\prime} 54^{\prime \prime}$ to $88^{\circ} 22^{\prime} 03^{\prime \prime}$ East longitude (Fig.1). Towards the east of the study area lies the town of HugliChinsurah municipality. Chinsurah is headquarter of the district Hugli.

Panchrakhi is located on the bank of river Saraswati and is a part of the flood plain of river Hooghly. In general, this region occupies a monotonous low lying tract has been lesser elevation above sea level, average altitude of the plain is 25 feet above sea level. The constructional slope of this area is from east to west as indicated by the direction of flow of river Saraswati, a dead and decaying river. Naturally, the entire geological structure is marked by alluvial deposits of river Hooghly and Saraswati.

This area have experienced monsoon climate. During winter season mean temperature is about $17^{\circ} \mathrm{C}$ and in summer season it is $32^{\circ} \mathrm{C}$. The mean annual precipitation is $120-150 \mathrm{~cm}$. The highest rainfall has occurred during the months of July and August. The suitable physical and climatic conditions allow enough dynamicity in land use and land cover of the region.

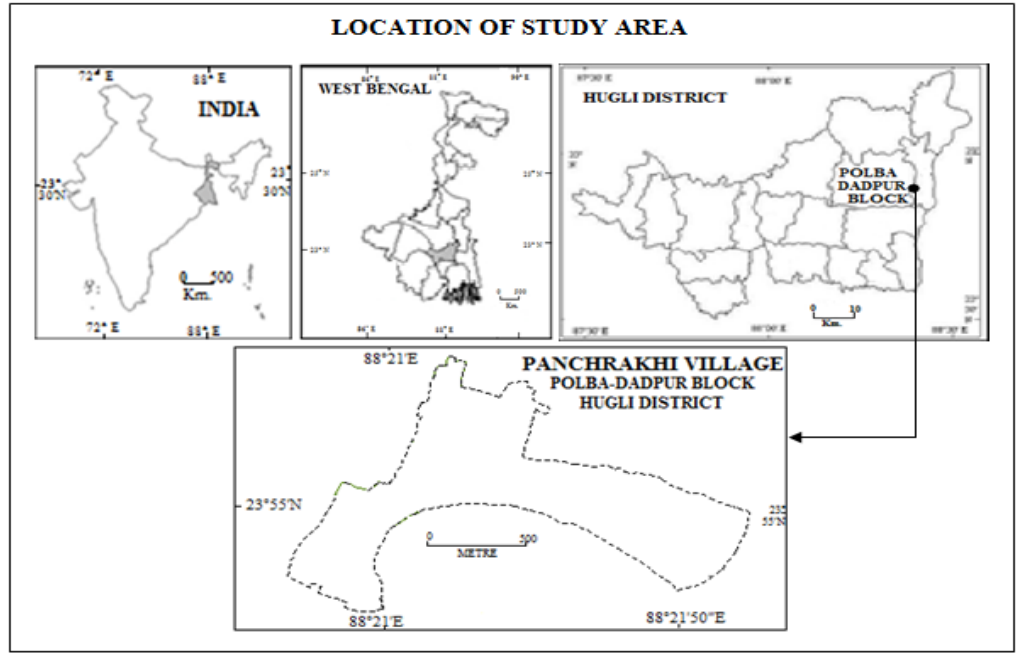

Fig. 1

\section{Objectives of the Present Study}

The main purpose of the present study is to monitor land use and land cover change and create credible information about the landscape which might be useful for taking fundamental decision, planning and environmental management of the concerned region. The present study also try to find out the factors which are responsible for changing land use land cover of the village Panchrakhi. 


\section{Land Use and Land Cover of Study Area}

Panchrakhi is predominantly an agricultural area. This area has been brought under Special Area Development Programme. Much importance has given to the growth of more production and hence several modern techniques and other necessary arrangements have been adopted here for increasing agricultural production. So, here the land use and land cover pattern is very dynamic in nature. Thus for studying the dynamicity of land use and land cover of the concerned region, we have designed our own classification system for proper harmonization and validation.

\subsection{Agricultural Land}

Agricultural land denotes the land suitable for agricultural production, both crops and livestock. The standard classification (used by FAO) divides agricultural land into the following components which are arable land, orchards and pastures. To identify agricultural land, we have taken help from Survey India Topographical map; cadastral map and also plot to plot land use survey have been adopted. The utilization of land depend on physical factors like, topography, soil, climate as well as upon human factors such as density of population, duration of occupation, land tenure, profit and so on. In the study area most of the agricultural lands are devoted for orchard farming.

\subsection{Natural Vegetation Cover}

Vegetation is a general term use to refer the plant life of a region. In the present work we include the entire natural vegetative patches viz. Shrubs, grasslands and woody trees, bamboo groves etc. Mainly temperate deciduous types of trees are found in the study area. It has been observed that there is no remarkable forested part in the study area and the primary vegetation type is deciduous and shrubs which have severely degraded from the region for increasing demand of agricultural land and population pressure.

\subsection{Built up Area}

We can defined built up areas as land are occupied for residential, commercial, educational and any other infrastructural purposes including both built up areas and associated vegetated areas. In the present study we consider settled areas, areas under transportation network, greeneries and orchards with households, any other commercial and industrial buildings as built up areas.

\subsection{Water Bodies}

A body of water accumulated over the land and covered the topographically depressed areas. It includes large accumulation of water such as oceans, seas, rivers and lakes etc and small body of water like ponds, bills etc. They also vary in nature, some of them are flowing in nature but some are stationary. Sometimes they are manmade, though in most cases we have found natural water bodies.

\subsection{Fallow Lands}

This category includes all that land which was used for cultivation but is temporarily out of cultivation. Fallow land is of two types: current fallow and fallow other than current fallow. Follow of one year is called 'current fallow' while that of two to five years is classified as 'fallow other than current fallow'. In the study area, we have found mostly current fallow lands which are not cultivated in the current year due to some socio economic or personal problems of the land owners.

\section{Results and Discussion}

Land use land cover study and maps over Panchrakhi village have identified five general categories of land use and land cover types for the year1974 to 2014(Fig. $2 \& 3$ ). The study area is agriculturally developed enough in Hugli district. So, it is quite common that agriculture dominates all other land use and land cover categories and comprises more than half of the total area (Table 1). We have extended our study to category wise land use land cover analysis just to identify and explore the reality (Fig. 4 to 9). 


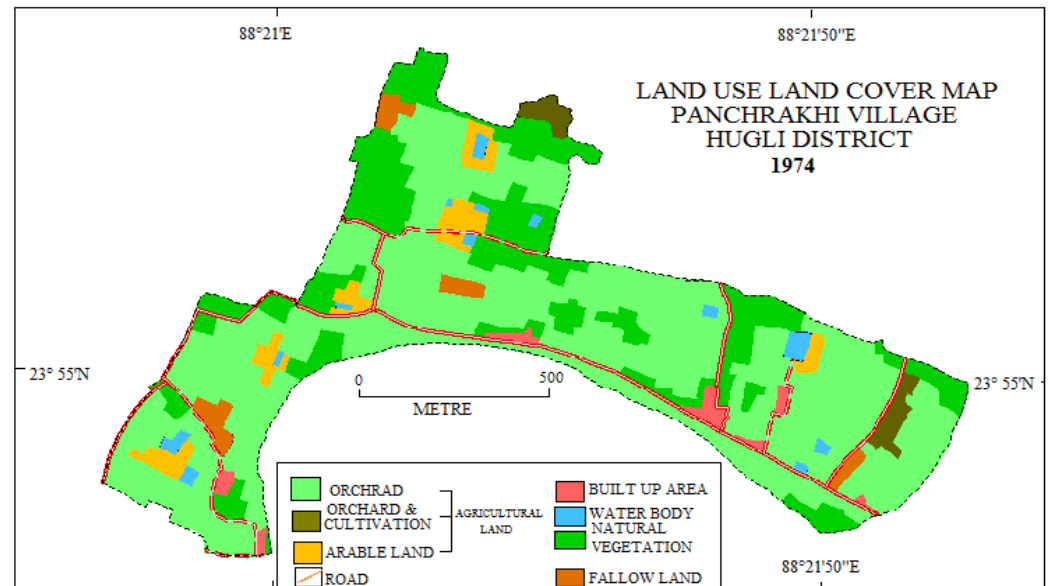

Fig. 2

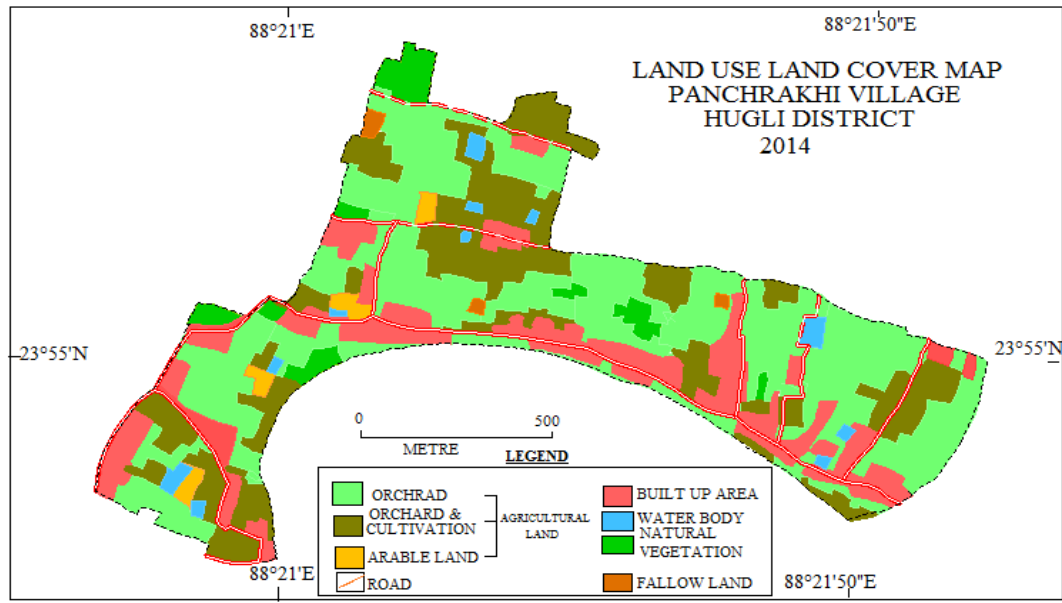

Fig. 3

Table 1: Comparative Analysis of the Distribution of Land Use and Land Cover

\begin{tabular}{|c|c|c|c|c|c|c|}
\hline $\begin{array}{l}\text { Land Use \& Land Cover } \\
\text { Categories }\end{array}$ & \multicolumn{2}{|c|}{1974} & \multicolumn{2}{|c|}{2014} & $\begin{array}{l}\text { Positive/ Negative } \\
\text { Change in } \\
\text { hectare(1974-2014) }\end{array}$ & $\begin{array}{c}\text { Positive/ } \\
\text { Negative } \\
\text { Change in \% } \\
(1974-2014) \\
\end{array}$ \\
\hline Built up Area & 2.1052 & 1.9 & 16.62 & 15 & 14.5148 & 13.1 \\
\hline Natural Vegetation & 24.1544 & 21.8 & 4.5428 & 4.1 & -19.6116 & -17.7 \\
\hline Water Body & 1.9944 & 1.8 & 1.8836 & 1.7 & -0.1108 & -0.1 \\
\hline
\end{tabular}

Source: Computed by authors

COMPARATIVE ANALYSIS OF LAND USE \& LAND COVER DISTRIBUTION

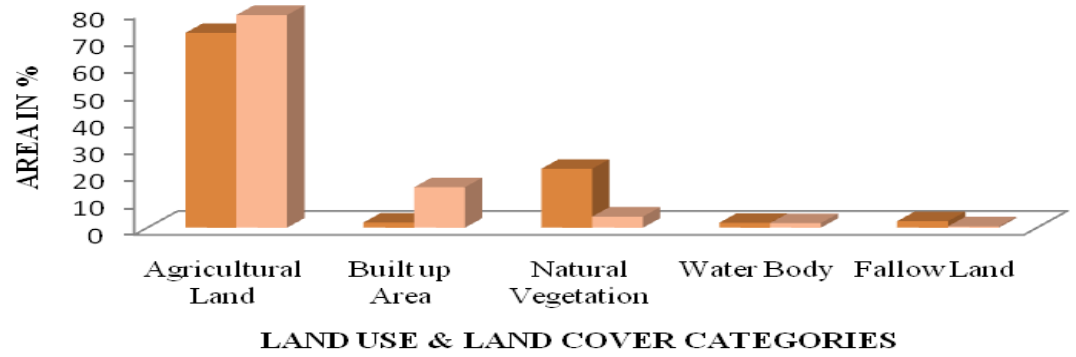

Fig. 4 


\subsection{Change in agricultural land use}

There is a steady increase in the agricultural land use. Mainly, the natural vegetation cover, fallow lands are occupied to increase the agricultural practices. In the year 1974 agricultural land consist 72.1 percent area of the region which increased up to 6.6 percent of the total area during the temporal analysis extended from 1974 to 2014 ( Table1). Agricultural land has increased from 79.88 hectare in 1974 to 87.19 hectare in 2014 . Most of the agricultural lands are occupied for orchard farming. Agricultural land use of the study area can be divided into three types-
i. Only orchard farming (Mango predominant).
ii. Orchards farming with vegetable cultivation
iii. Arable land

If we consider the agricultural land use scenario, orchard farming (especially mango) is the dominant land use pattern of the study area. A significant change has been observed in agricultural practices over the last 40 years. Previously, only orchard farming was the dominant land use pattern of the study area but in recent times, most of the orchards are transformed to orchard farming with inter cultivation. The percentage of only orchard land holdings to overall farm land of the Panchrakhi village has also decreased from $91.5 \%$ in 1974 to $67.9 \%$ in 2014. On the contrary, the land holdings of orchard farming with inter cultivation has increased steadily. In 1974, only two hectare area was devoted for orchard farming with cultivation which increased up to 23.8 hectare during this 40 year time span and now orchards farming with cultivation have occupied 30.3 percent area to the total agricultural land holdings. On the other hand, the share of arable land (land devoted for any agricultural practices except orchard farming) have reduced 1.4 hectare and at present it consists of 1.8 percent area to over all agricultural land (Table 2 \& Fig. 5).

Table 2: Comparative Analysis of the Distribution of Agricultural Land

\begin{tabular}{|c|c|c|c|c|c|c|}
\hline \multirow{2}{*}{$\begin{array}{c}\text { Types of } \\
\text { Agricultural Land }\end{array}$} & \multicolumn{2}{|c|}{1974} & \multicolumn{2}{|c|}{2014} & \multirow{2}{*}{$\begin{array}{c}\text { Positive/ } \\
\text { Negative } \\
\text { Change in } \\
\text { hectare } \\
(1974-2014) \\
\end{array}$} & \multirow{2}{*}{$\begin{array}{c}\text { Positive/ } \\
\text { Negative } \\
\text { Change in } \\
\%(1974- \\
2014 \\
\end{array}$} \\
\hline & $\begin{array}{l}\text { Area in } \\
\text { Hectare }\end{array}$ & $\begin{array}{l}\text { Are in \% to total } \\
\text { agricultural land }\end{array}$ & Area in Hectare & $\begin{array}{l}\text { Are in \% to total } \\
\text { agricultural land }\end{array}$ & & \\
\hline Orchard Farming & 66 & 91.5 & 53.5 & 67.9 & -12.5 & -23.6 \\
\hline $\begin{array}{c}\text { Orchard farming } \\
\text { \& Cultivation }\end{array}$ & 2 & 2.8 & 23.8 & 30.3 & 21.8 & 27.5 \\
\hline Arable bland & 4.1 & 5.7 & 1.4 & 1.8 & -2.7 & -3.9 \\
\hline
\end{tabular}

Source: Computed by authors

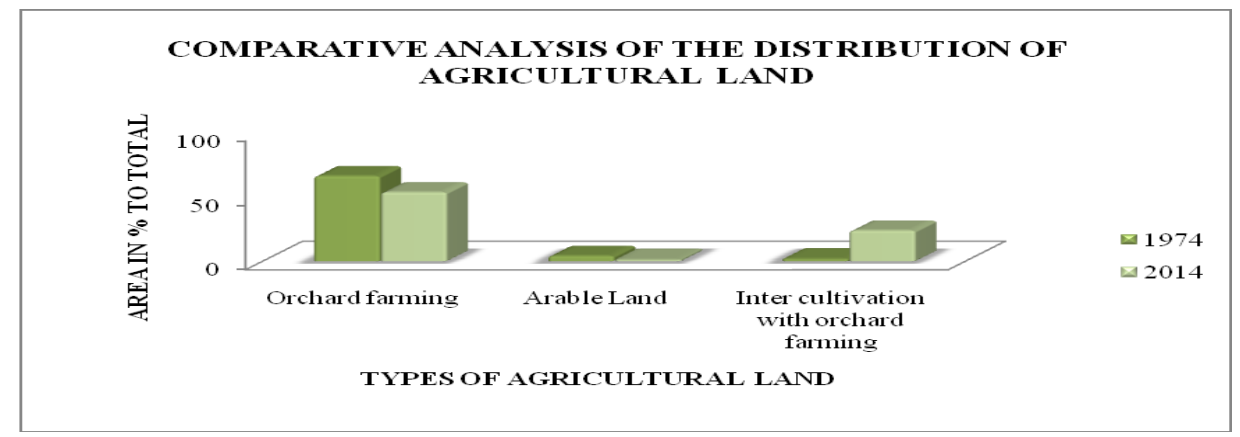

Fig. 5

In orchard farming, there is a peak season and lean season. Peak season means when production is expected enough and lean season is characterized by very low or no production. In Panchrakhi village lots of local people are engaged in orchard farming and in many cases, it is their only livelihood. So, in lean season small orchard owners have no opportunity of earning their livelihood. Consequently, in recent times, most of the small orchard owners are interested in orchard farming with inter cultivation for profit maximization and risk minimization.

\subsection{Built up area and land use change}

Present study reveals that the second major land use class is the built up area. The built up land have increased from $1.9 \%$ in 1974 to $15 \%$ in 2014 showing that the region is affected by population pressure. Though this area has a rural base but Chinsurah( the headquarter of district Hugli) is not very far from this area The village settlement of Panchrakhi are built along the pre defined lines, ranging from straight, curved and parabolic alignment along the road or transport route, active river channels and flood plain rises, especially 
along the levees. The size of the settlement also varies from small nucleated to cluster. During 1961-2011 population of Panchrakhi village has increased from 371 to 903 (Fig.6). No doubt, increasing population pressure is an important factor to expand the share of built up area but there is another specific cause behind the expansion of built up area. A 'Technique Polytechnic Institute' was established here on 2008. Consequently, various students are attracted by this institute and many residential houses or other accommodations for the students and teachers have developed.

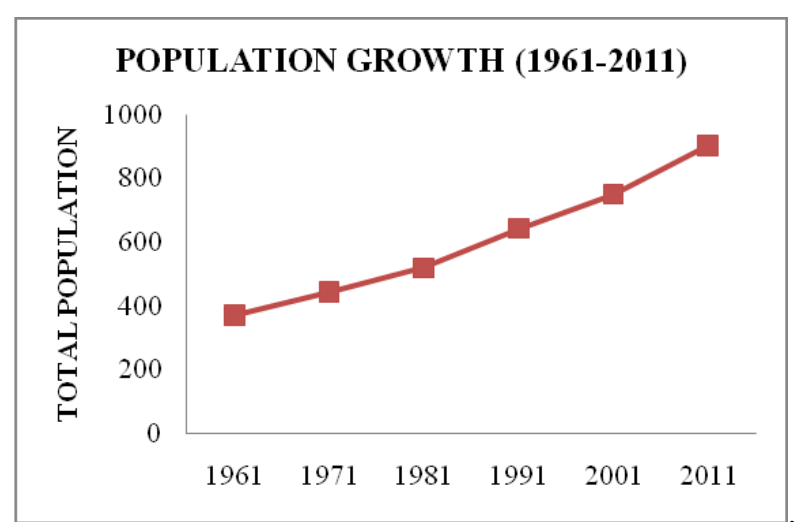

Fig. 6

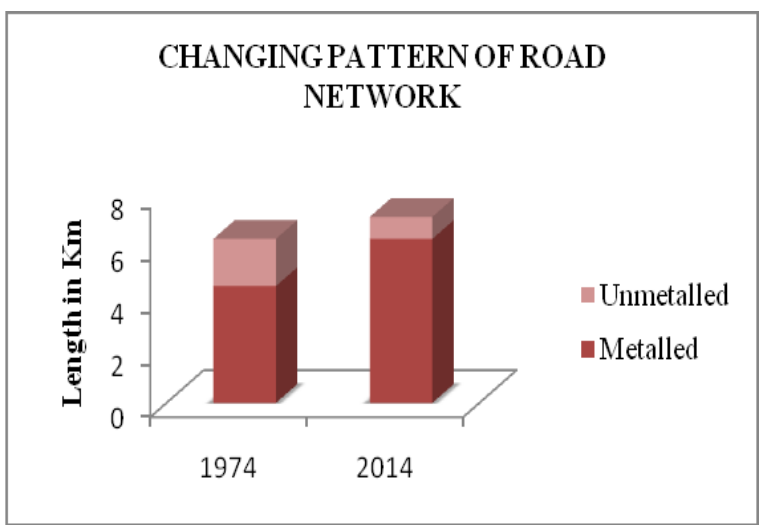

Fig. 7

Still now, the transport system of the study area is not well developed but there is a sign of progress. In1974, the total length of roads (metalled and non- metalled) was $6.3 \mathrm{~km}$. In 2014 it has become $7.2 \mathrm{~km}$; though, the development in transport scenario is very poor but few roads are transformed from non-metalled to metalled one (Fig.7).

\subsection{Natural vegetation and land cover change}

Natural vegetation is one of the major components of the environmental system and plays an important role on direct and in direct ways to maintain the ecological stability. But with increasing population and unconscious human desires the natural vegetation of the major flood plains of the world are under massive destruction which not only threatens the plant diversity but also leaves a negative imprint on the regional ecological community. The lower gangetic plain is not an exception; much of its natural vegetation is destroyed at the cost of urban and agricultural growth. The area under study situated on the bank of the river Saraswati has tropical and sub-tropical deciduous type of vegetation is now in severely degraded condition. Maximum natural vegetation is vanished due to anthrop genetic activities. Our analysis reveals that $17.7 \%$ area (Table 1) under natural vegetation is engulfed by the pace of development from1974-2014. But this is not a healthy trend and must be checked at any costs.

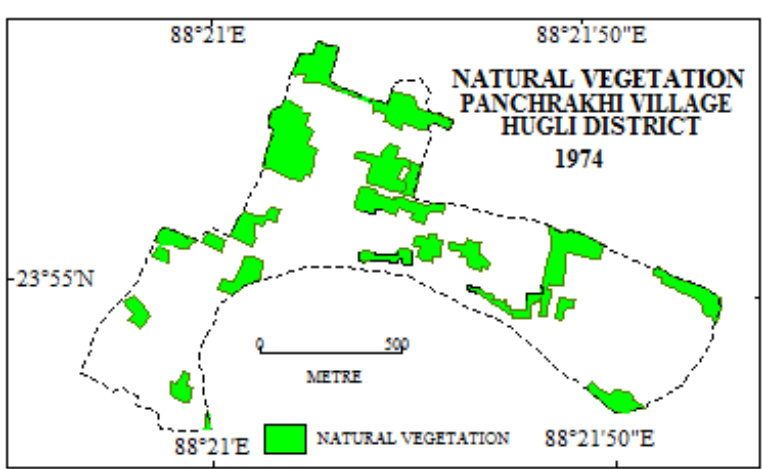

Fig. 8

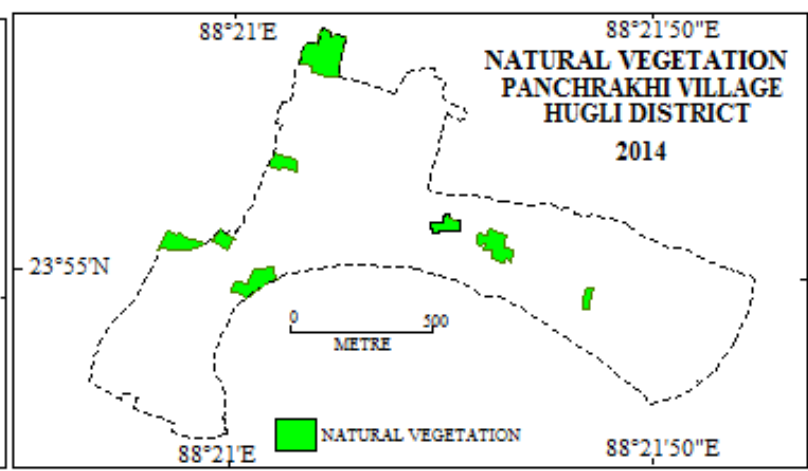

Fig. 9

\subsection{Water body and land cover change}

Surface water bodies have significant role on the land use and land cover pattern, especially on the agricultural practices and irrigation. The use of the surface water is consider as the major environmental control strategy different types of water bodies, i.e., ponds, bills etc. These are also varying in nature, some are permanent and some are semi permanent. The total surface water body in the region covers 1.8 percent in 1974 and there is negligible change in this scenario. In 40 years (1974-2014) temporal analysis it experiences minute reduction of 0.1 percent (Table-1). 


\subsection{Fallow land and changing pattern}

The topographical map and cadastral map did not provide any opportunity to identify fallow land but the valuable opinion and judgement of the local people and plot to plot land use and land cover survey help us to identify and analyse the changing nature of fallow land throughout study period extended from 1974-2014.It covers almost $2.4 \%$ of total land resource in the year 1974, which decreased up to $1.9 \%$ and acquires only $0.5 \%$ of the total land area(Table-1).It reveals that gradually due to extension of irrigation, cultivation of multiple crops and mechanized agricultural techniques, the fallow land have decreasing day by day and more and more land resource are coming under intensive human practice of economic consideration.

\section{Findings and Conclusion}

Within the framework of present discourse, for the detection of possible land use and land cover changes, monitoring and evaluation in Panchrakhi village using topographical map, cadastral map and plot to plot land use and land cover survey is easily realised. The result of present work indicates there have been important land use land cover changes in between 1975 to 2014 time periods in the study area. The statistical analysis shows that the major changes have been occurred in vegetation cover, open space, agriculture and built up categories. Both vegetation cover and open space decreased where as built up area have increased up to considerable amount. The study shows that natural landscape covered with vegetation are destructed and used for cultivation and building roads, homestead and many other new set-ups. It is happened due to improved agricultural technologies, extension of irrigation facility, use of high yielding seed and multi-crop cultivation; whereas built up area have been increasing for population pressure and infrastructure development and it accounts for \% in 1975 to \% in 2014 in respect of total land of the village Panchrakhi. It is evident from our study that the share holdings of agricultural land is not growing rapidly but there is a significant change in agricultural practice which have a powerful impact on the land use pattern of the concerned region. Most of the orchard lands holdings are converted to orchard farming with inter cultivation. This is happened due to profit maximization and risk minimization of the orchard owners. So, it can be cropped up that land use of ecological signature is gradually engulfed by land use of economic consideration.

\section{References}

[1] P.K.Sharma, B.P. Lahkhar, Ghosh, A.Rabha, J.P. Das, N.K. Dey, N.Brahma, Land-use Land-cover Change and Future Implication Analysis in Manas National Park, India, Using multi-temporal satellite data, Current Science, 95 (2),2008,223.

[2] A. Smith, An Inquiry into the Nature and Causes of the Wealth of Nations (Liberty Fund: Indianopolis, 1776)

[3] A. Marshall, Principles of Economics (London: Macmillan, 1890).

[4] A.A. Klingebiel, and P.H. Montgomery, Land Capability Classification, USDA-SCS Agricultural Handbook (210. U.S. Gov. Print. Office, Washington, DC, 1961).

[5] N. Hudson, Soil Conservation (London, B.T.Batsford Ltd, 1971)

[6] A. Young, Tropical Soils and Soil Survey (Cambridge: Cambridge University Press, 1976) 468.

[7] G.W. Olson, Land Classification. Search, Agriculture, 4 (New York: Cornel University, Ithaca, 1974$) 34$

[8] S.P. Chatterjee, The place of geography in national planning, Geographical Review , (3), 1941

[9] S.P. Chatterjee, Land utilization in the district of 24 Paraganas, Bengal, Geographical Review (2), 1945.

[10] S.P. Chatterjee, Land utilization survey of Howrah District, Geographical Review of India, XIV (3), 1952.

[11] S. N. Mukherjee, Agricultural Planning in Howrah, Geographical Review of India, 1967.

[12] A. ROY, Landuse and major agricultural characteristics of the Damodar-Saraswati Doab, Geographical Review of India, 34(1), $1972,28-35$.

[13] S. Chatterjee and M.M. Jana, The pattern of land utilizationand around Tarakeswar town, Geographical Review, India, $37(1)$, 1975.

[14] S. Chattopadhyay, Hydrology and landuse in the littoral tract of deltaic West Bengal, Calcutta,Geographical Review, 42,177-180.

[15] A. Singh, Digital Change Detection Techniques using Remote Sensing Data, International Journal of Remote Sensing, 10 (6), 1989, 989-1003.

[16] S. Roy. and A. Giriraj, Land-use Land-cover Analysis in Indian Context, Journal of Applied Sciences,8 (8), 2008, 1346-1353.

[17] C. Prakasam, Land Use and Land Cover Change Detection through Remote Sensing Approach: A CaseStudy of Kodaikanal Taluk, Tamil Nadu, India. International Journal of Geomatices and Geosciences, 1(2), 2010. 